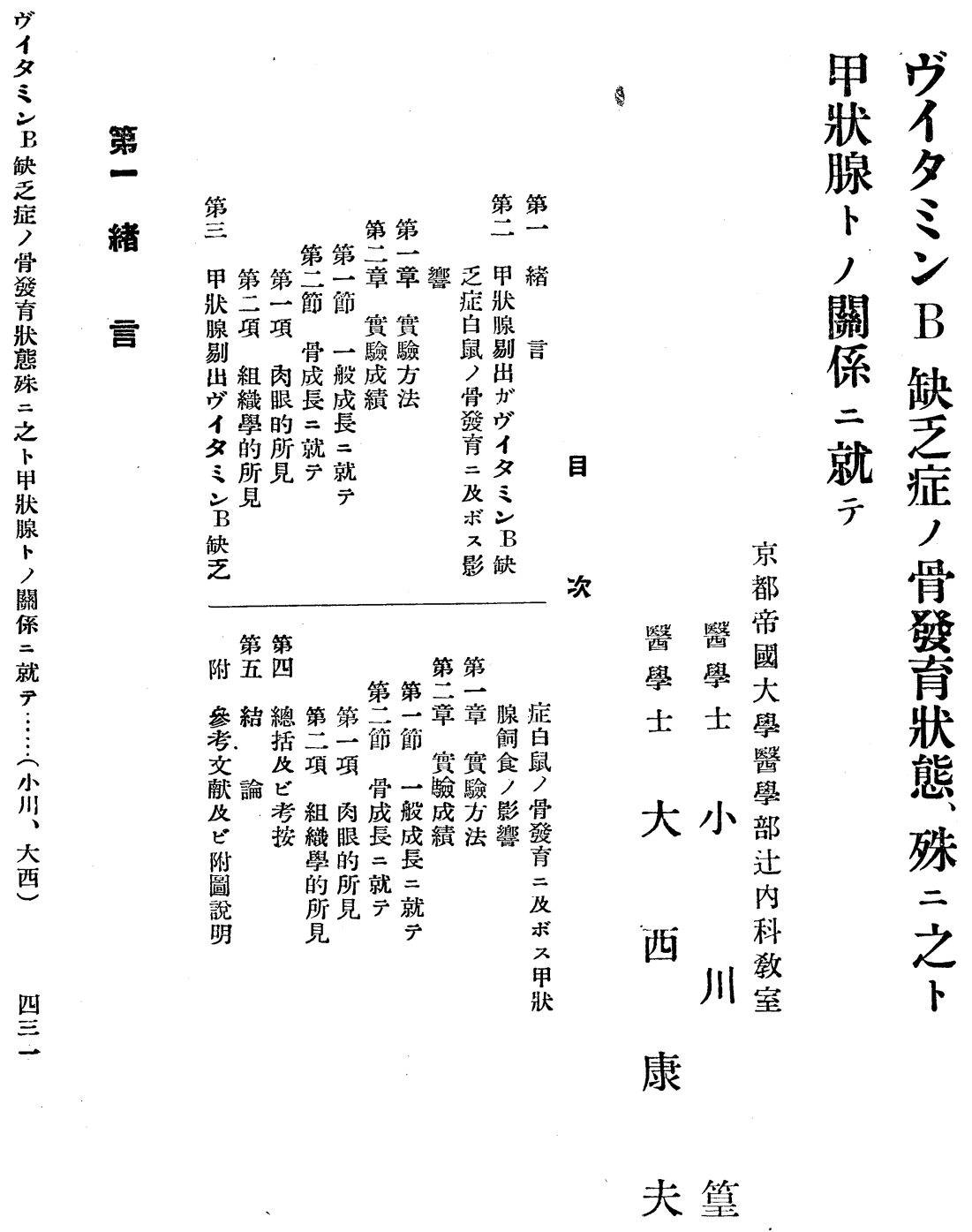




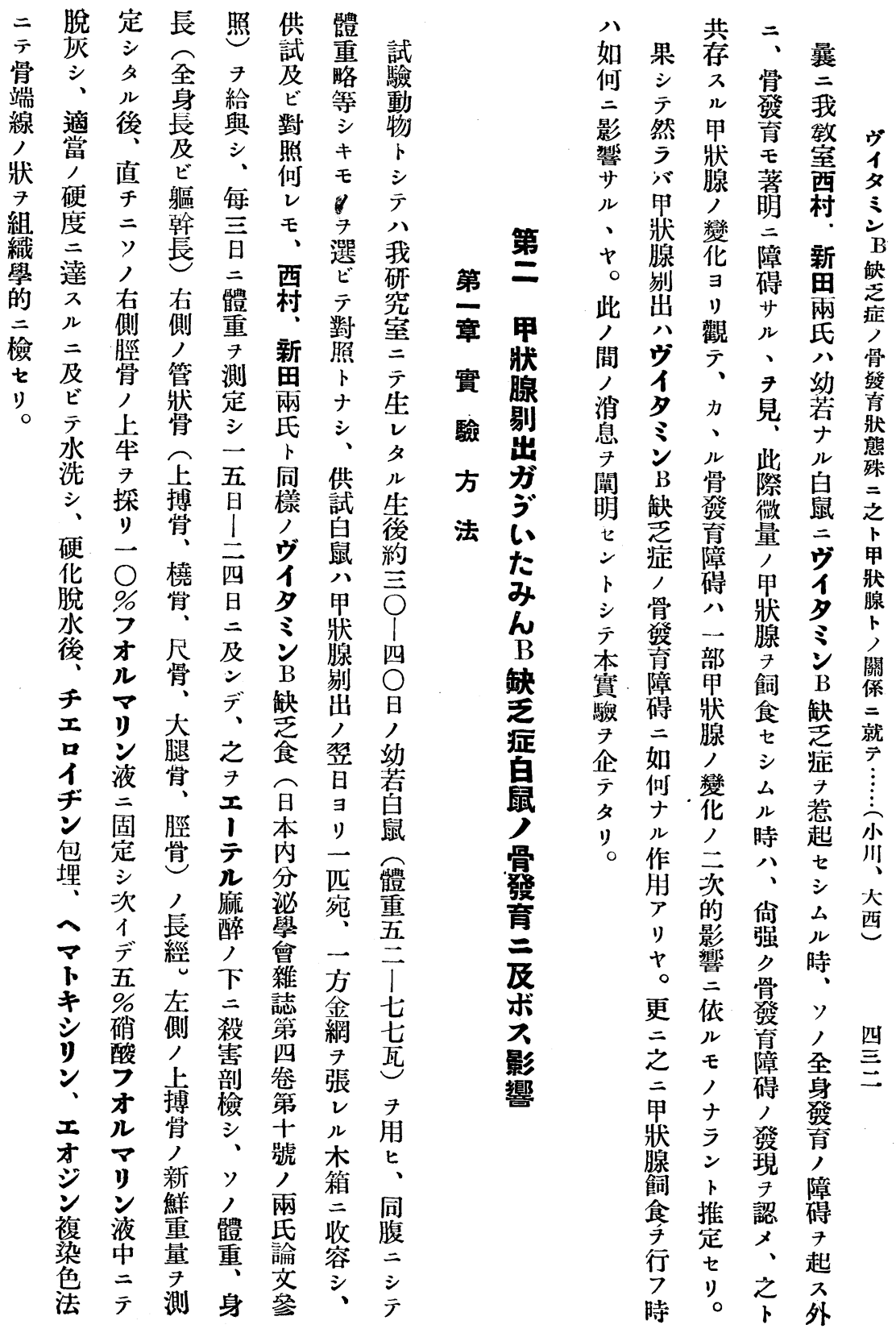


第一圖 甲枵腺剔出ヴイタミンB缺乏鿊白鼠 >體重曲線

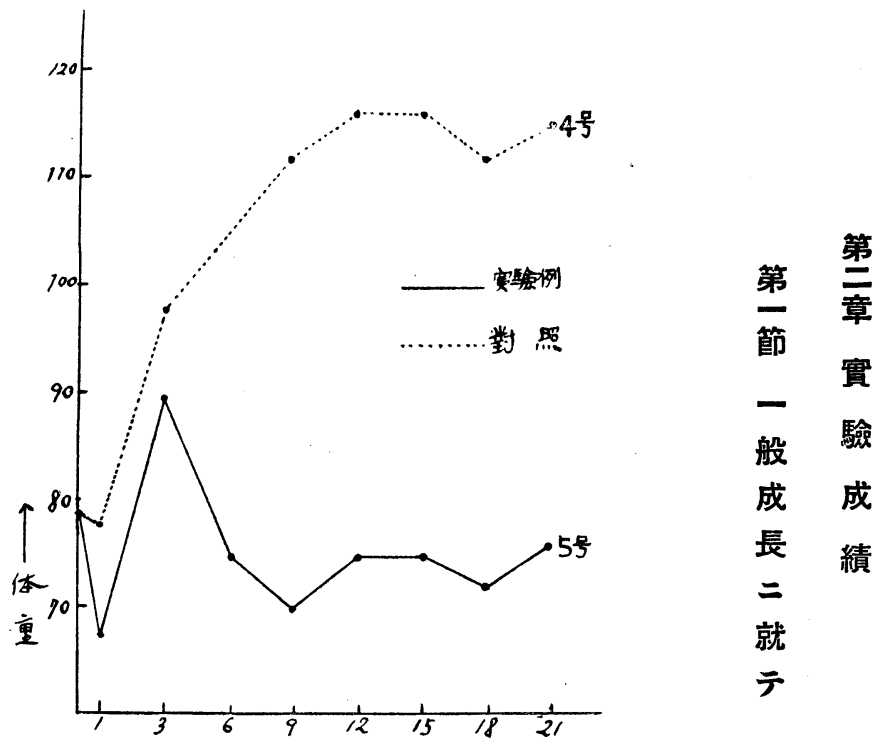

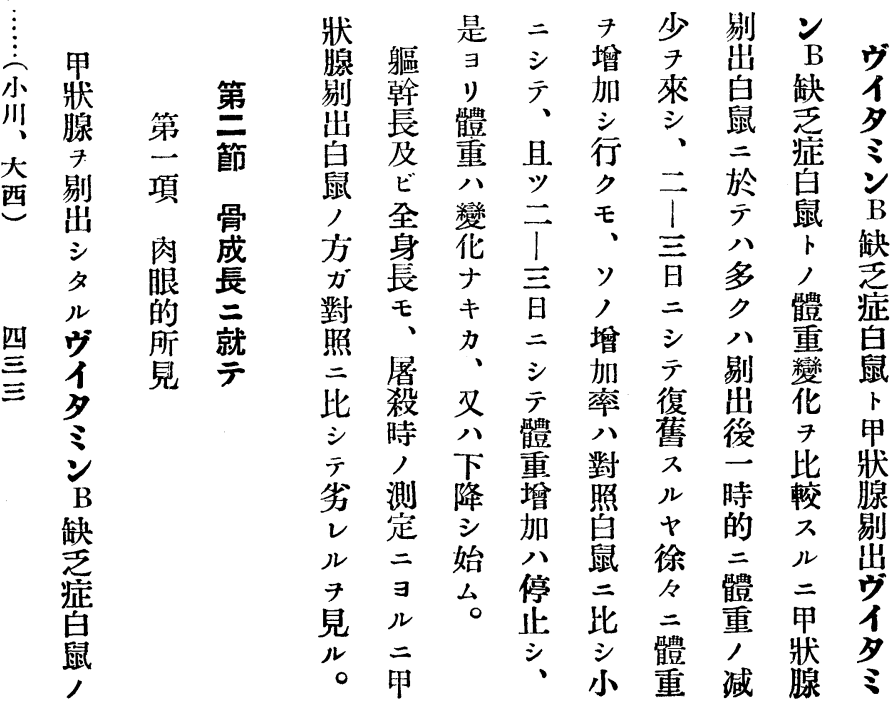


第一表 ヴイタミンB缺泛症白鼠ノ甲狀腺剔出及ビ之二甲

狀腺創食ナナセル時ノ體重變化（單位瓦)

\begin{tabular}{|c|c|c|c|c|c|c|c|c|c|c|c|c|}
\hline \multirow{2}{*}{$\begin{array}{l}\text { 動物 } \\
\text { 番號 }\end{array}$} & \multirow{2}{*}{ 處 置 } & \multirow{2}{*}{ 些 } & \multicolumn{10}{|c|}{ 試驗開始後 ノ日數 } \\
\hline & & & 前 & 1 & 3 & 6 & 9 & 12 & 15 & 18 & 21 & 24 \\
\hline 1 & 剔 & $\hat{\delta}$ & 65 & 58 & 75 & 68 & 70 & 80 & 80 & & & \\
\hline 2 & 剔出飼食 & $\hat{\boldsymbol{s}}$ & 60 & 53 & 65 & 62 & 61 & 61 & 60 & & & \\
\hline 3 & 對 & q & 52 & 57 & 65 & 67 & 72 & 82 & 84 & & & \\
\hline 5 & 剔 & 占 & 77 & 67 & 90 & 75 & 70 & 74 & 75 & 72 & 75 & \\
\hline 6 & 剔百飼食 & + & 77 & 69 & 80 & 67 & 81 & 76 & 73 & 73 & 75 & \\
\hline 4 & 對 & $\hat{s}$ & 77 & 77 & 98 & 104 & 112 & 116 & 116 & 112 & 117 & \\
\hline 9 & 剔 & q & 53 & 50 & 57 & 57 & 58 & 54 & 60 & 57 & 55 & \\
\hline 10 & & 占 & 57 & 53 & 68 & 66 & 63 & 62 & 66 & 66 & 65 & \\
\hline 7 & 剔出飼食 & 우 & 53 & 47 & 57 & 50 & 54 & 53 & 50 & 45 & 42 & \\
\hline 8 & 剔出飼食 & i & 52 & 48 & 61 & 55 & 53 & 52 & 53 & 49 & 45 & \\
\hline 11 & & 占 & 57 & 58 & 68 & 75 & 83 & 92 & 97 & 97 & 94 & \\
\hline 21 & & q & 53 & 48 & 62 & 50 & 51 & 55 & 57 & 51 & 49 & 50 \\
\hline 19 & 剔出飼食 & q & 64 & 58 & 70 & 65 & 58 & 59 & 55 & 52 & 46 & 40 \\
\hline 20 & 對 & ㅇ & 60 & 59 & 69 & 75 & 83 & 92 & 97 & 93 & 89 & 80 \\
\hline
\end{tabular}

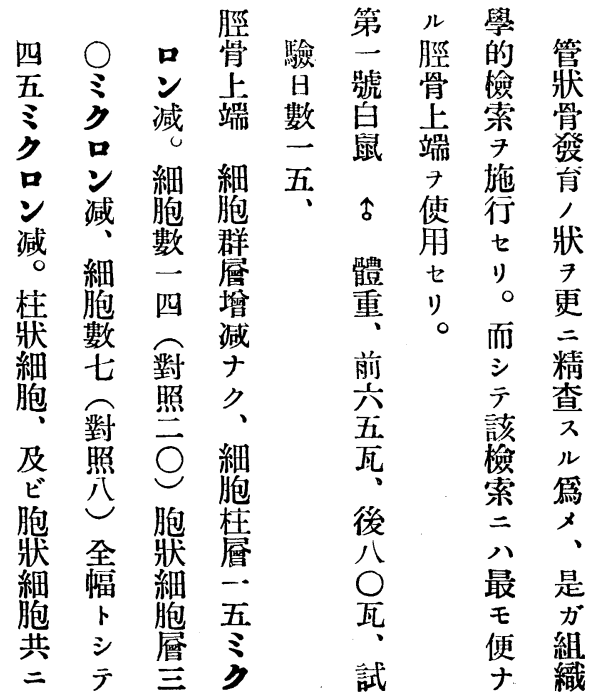


第二表 ヴイタミン B蚗乏庭白鼠〉甲狀腺剔出及ビ问

食時ノ管狀骨重量及ビ含水分量測定(單位瓦)

\begin{tabular}{|c|c|c|c|c|c|}
\hline 動物 & \multirow{2}{*}{ 處，置 } & \multirow{2}{*}{ 試驗日數 } & \multicolumn{2}{|r|}{ 搏 } & 骨 \\
\hline 番號 & & & 新鮮重量 & 乾燥重量 & 含水分量 \\
\hline 1 & 剔 & 15 & 0.139 & 0.068 & 0.061 \\
\hline 2 & 剔出飼食 & 15 & 0.123 & 0.066 & 0.057 \\
\hline 3 & 對 & 15 & 0.145 & 0.079 & 0.066 \\
\hline 5 & 剔 & 21 & 0.166 & 0.090 & 0.076 \\
\hline 6 & 剔屾飼食 & 21 & 0.160 & 0.087 & 0.073 \\
\hline 4 & 對 & 21 & 0.212 & 0.115 & 0.097 \\
\hline 9 & 剔 & 21 & 0.132 & 0.072 & 0.060 \\
\hline 10 & 剔 & 21 & 0.143 & 0.079 & 0.064 \\
\hline 7 & 剔出鶬食 & 21 & 0.127 & 0.064 & 0.063 \\
\hline 8 & 剔出飼食 & 21 & 0.121 & 0.061 & 0.060 \\
\hline 11 & 對 & 21 & 0.202 & 0.105 & 0.097 \\
\hline 21 & & 24 & 0.138 & 0.071 & 0.067 \\
\hline 19 & 剔出畮司食 & 24 & 0.131 & 0.068 & 0.053 \\
\hline 20 & 對 & 24 & 0.192 & 0.104 & 0.088 \\
\hline
\end{tabular}

テ

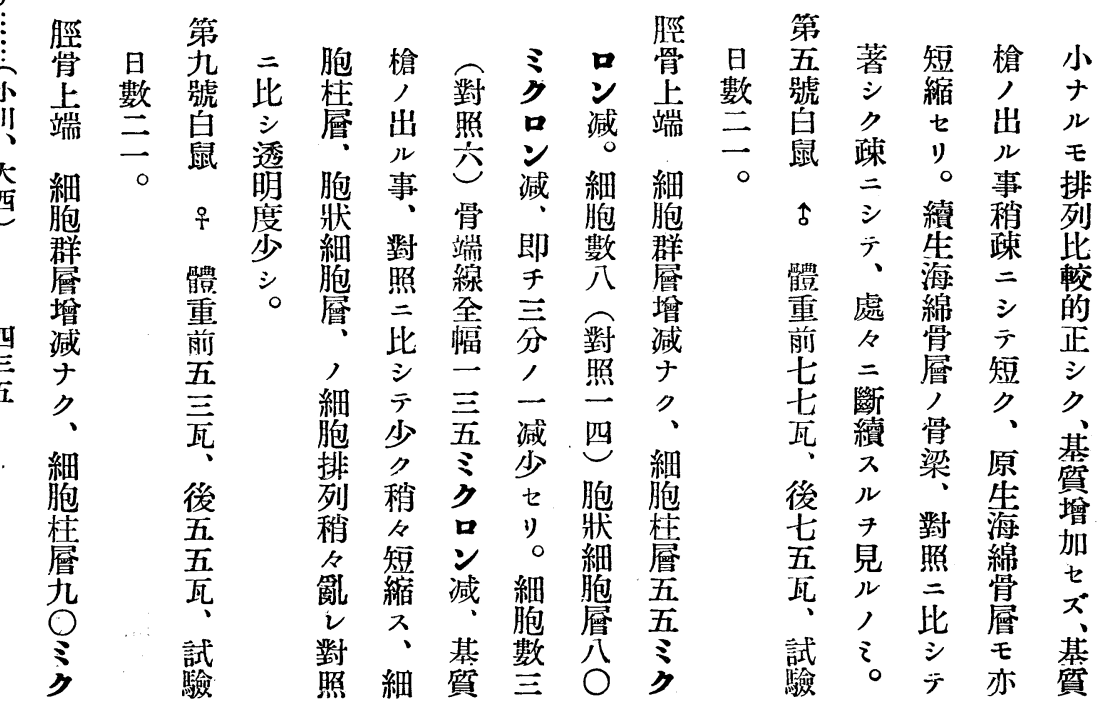


甲狀腺昡出ヴイタミンB缺乏症白鼠入脛骨上端ノ骨端線各層

つ检鏡的湖定（單位ミクロン、括弧內八本均細胞數キ示ス）

\begin{tabular}{|c|c|c|c|c|}
\hline 動物番號 & $\begin{array}{l}1 \text { (試驗) } \\
3 \text { (對照) }\end{array}$ & $\begin{array}{l}5 \text { (試驗) } \\
4 \text { (對照) }\end{array}$ & $\begin{array}{r}9 \text { (試驗) } \\
10 \text { (試驗) } \\
11 \text { (對照) }\end{array}$ & $\begin{array}{l}21 \text { (栻驗) } \\
20 \text { (對照) }\end{array}$ \\
\hline 骨端線全幅 & $\begin{array}{l}300 \\
345\end{array}$ & $\begin{array}{l}115 \\
250\end{array}$ & $\begin{array}{l}117 \\
137 \\
282\end{array}$ & $\begin{array}{l}114 \\
225\end{array}$ \\
\hline 細胞群 層 & $\begin{array}{l}15 \\
15\end{array}$ & $\begin{array}{l}15 \\
15\end{array}$ & $\begin{array}{l}12 \\
12 \\
12\end{array}$ & $\begin{array}{r}9 \\
15\end{array}$ \\
\hline$\{$ 細 胞 杜 尿 & $\begin{array}{l}135(14) \\
150(20)\end{array}$ & $\begin{array}{c}60(8) \\
115(14)\end{array}$ & $\begin{array}{c}60(7) \\
50(6) \\
150(15)\end{array}$ & $\begin{array}{r}60(10) \\
120(14)\end{array}$ \\
\hline 胞狀細胞層 & $\begin{array}{l}150(7) \\
180(8)\end{array}$ & $\begin{array}{r}40(3) \\
120(6)\end{array}$ & $\begin{array}{r}45(3) \\
75(4) \\
120(6)\end{array}$ & $\begin{array}{l}45(4) \\
90(6)\end{array}$ \\
\hline $\begin{array}{l}\text { 原 生 } \\
\text { 海綿骨層 }\end{array}$ & $\begin{array}{l}150 \\
300\end{array}$ & $\begin{array}{l}120 \\
150\end{array}$ & $\begin{array}{r}180 \\
96 \\
300\end{array}$ & $\begin{array}{l}115 \\
120\end{array}$ \\
\hline
\end{tabular}

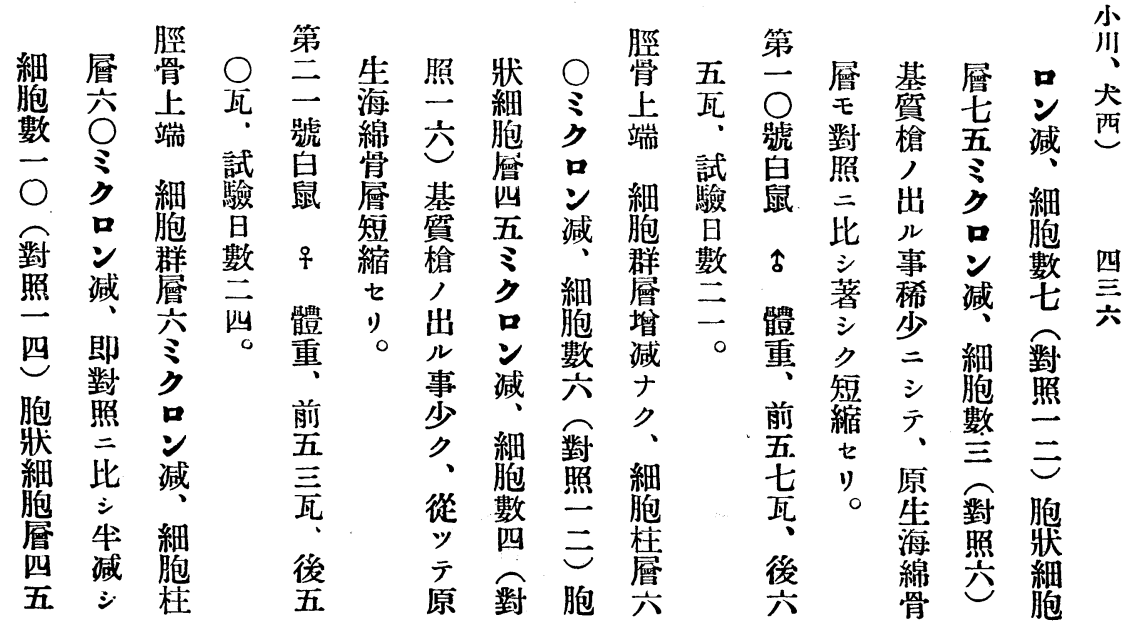




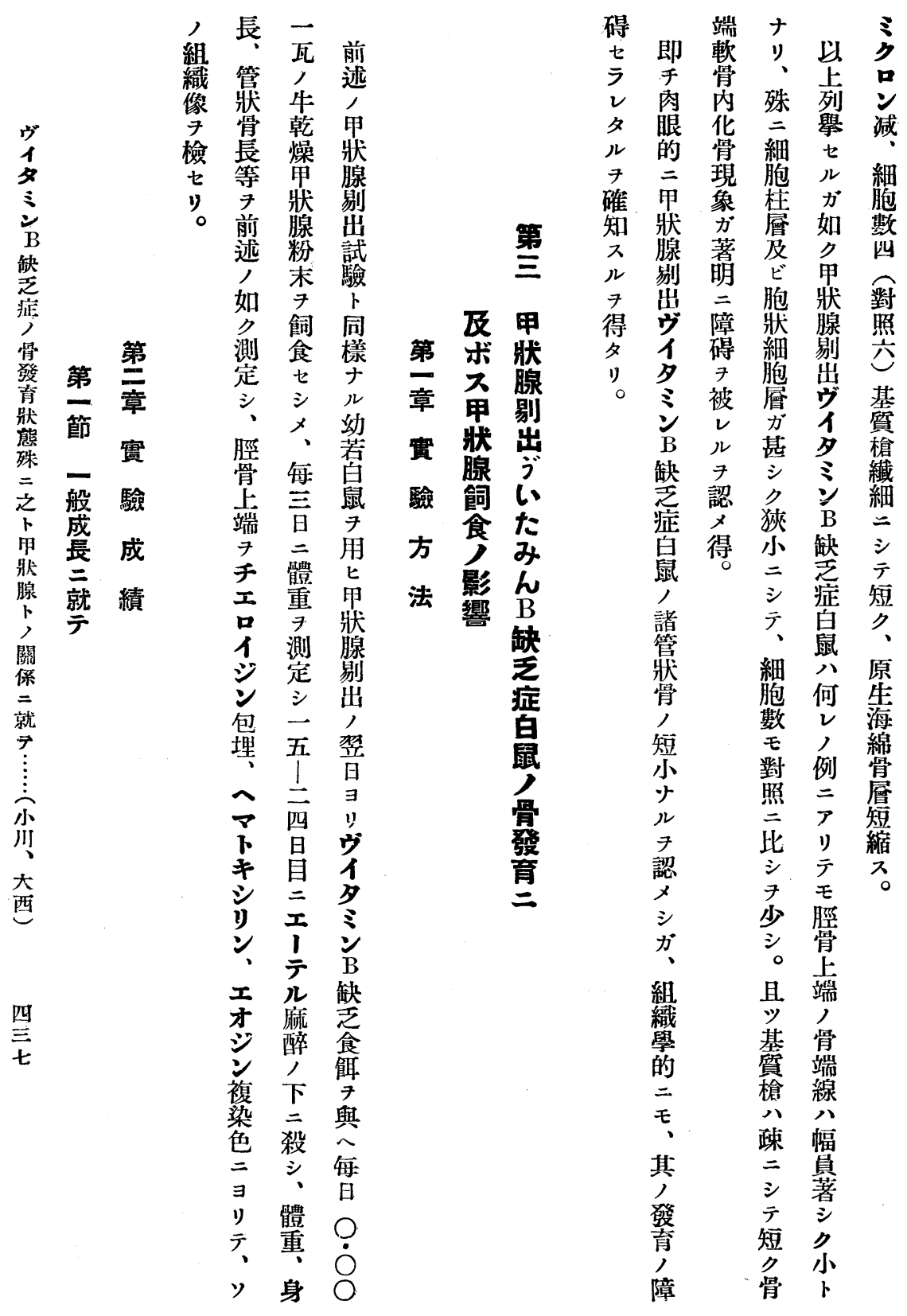


甲狀腺剔出ヴイタミンB 缺乏症白鼠二

甲狀腺鸽食キナセ几時ノ重量曲線
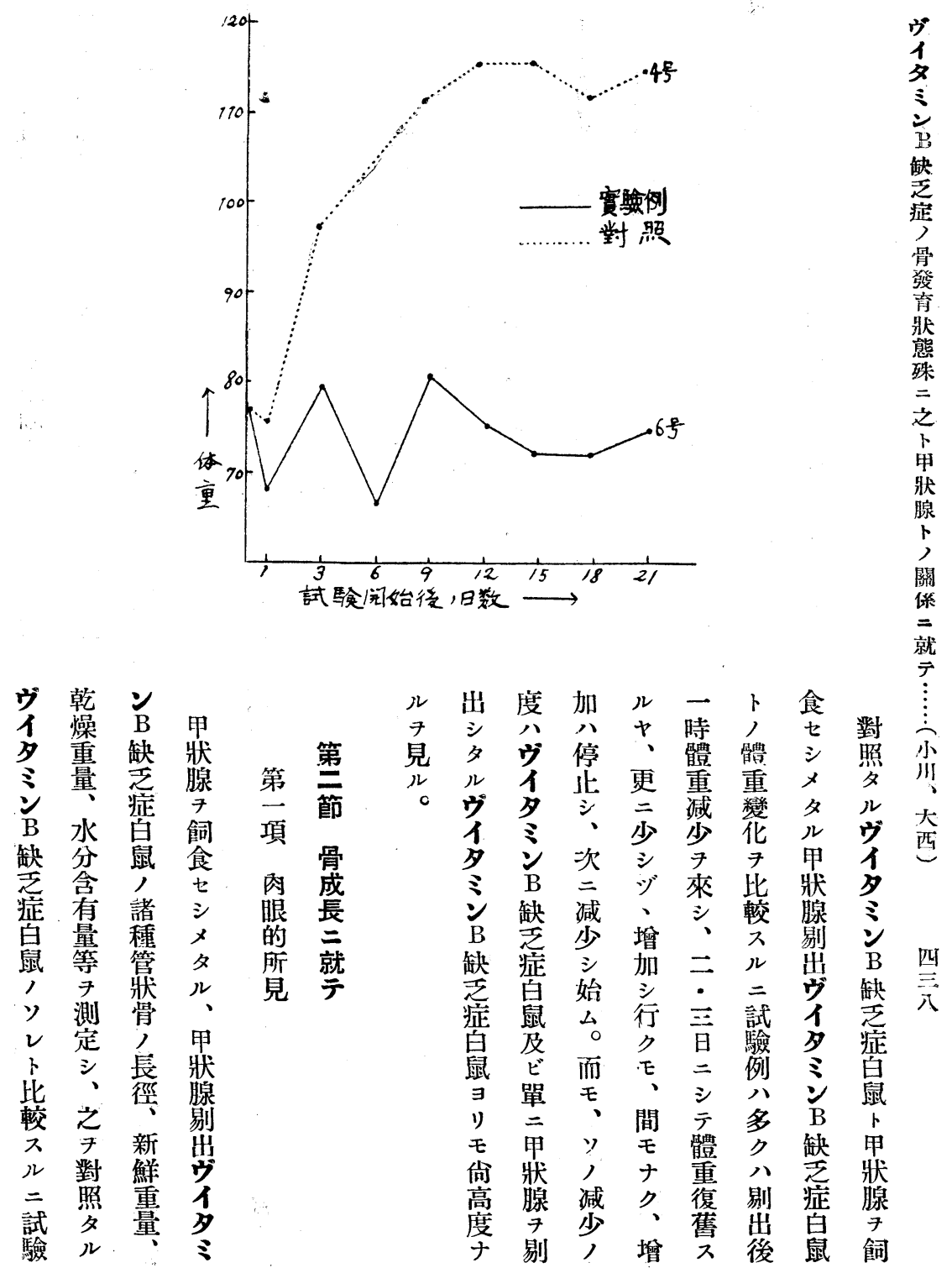


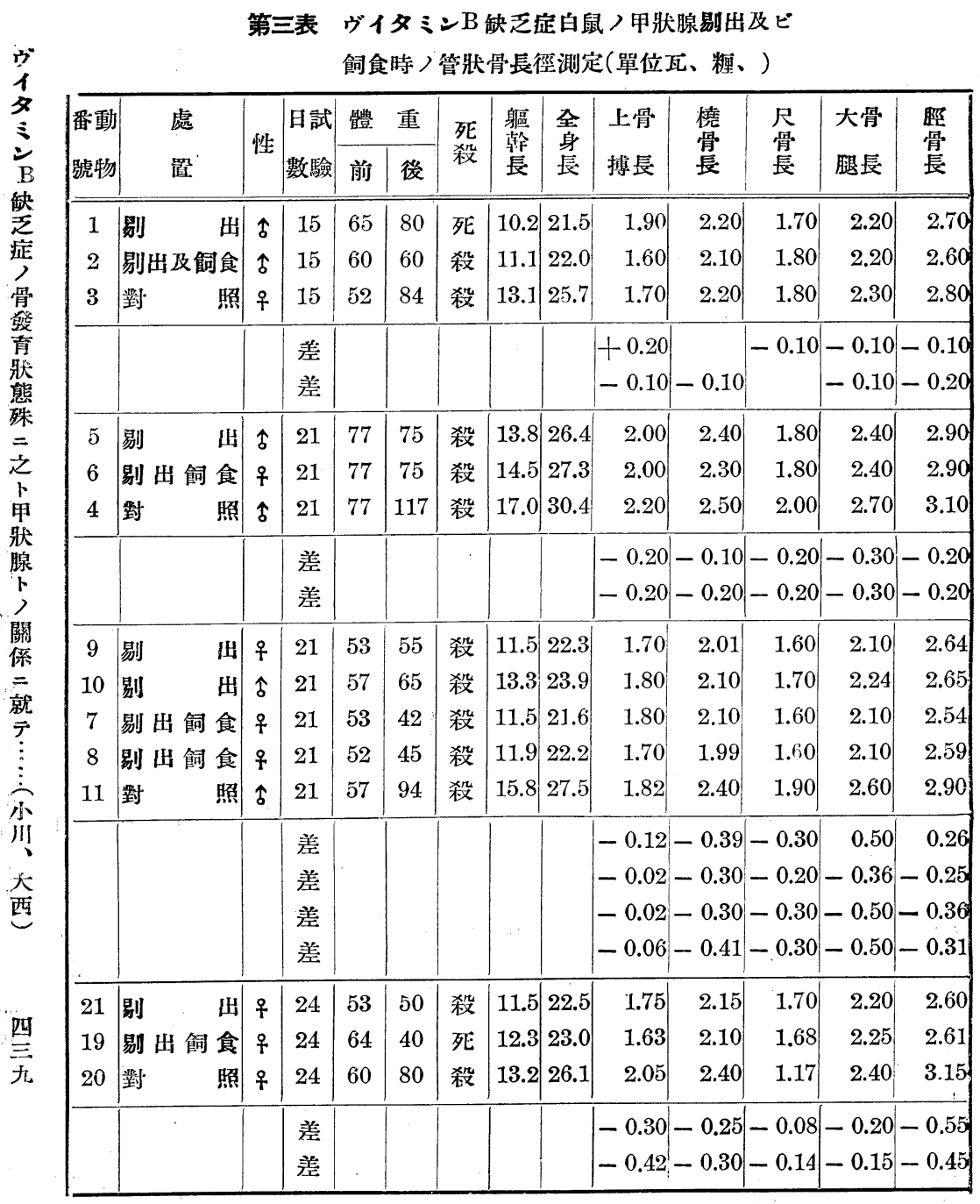


甲爿腺剔出ヴイタミン $\mathrm{B}$ 缺乏症白鼠二甲狀腺䧻食キ ナ七ル時ノ脛骨上端/骨端線各層/檢鏡的測定

(單位ミクロン、括弧內ハ本均細胞數き示ス)

\begin{tabular}{|c|c|c|c|c|}
\hline 動物番號 & $\begin{array}{l}2 \text { (試驗) } \\
3 \text { (對照) }\end{array}$ & $\begin{array}{l}6 \text { (試驗) } \\
4 \text { (對照) }\end{array}$ & $\mid \begin{array}{rr}7 & \text { (試驗) } \\
8 & \text { (試驗) } \\
11 & \text { (對照) }\end{array}$ & $\mid \begin{array}{ll}19 & \text { (試驗) } \\
20 & \text { (對照) }\end{array}$ \\
\hline 骨端線全幅 & $\begin{array}{l}150 \\
345\end{array}$ & $\begin{array}{l}134 \\
250\end{array}$ & $\begin{array}{l}114 \\
129 \\
282\end{array}$ & $\begin{array}{r}84 \\
225\end{array}$ \\
\hline 細胞群層 & $\begin{array}{l}15 \\
15\end{array}$ & $\begin{array}{r}9 \\
15\end{array}$ & $\begin{array}{r}9 \\
9 \\
12\end{array}$ & $\begin{array}{r}9 \\
15\end{array}$ \\
\hline 細 胞 桂 層 & $\begin{array}{c}75(6) \\
150(20)\end{array}$ & $\begin{array}{c}70(8) \\
115(14)\end{array}$ & $\begin{array}{c}60(8) \\
75(8) \\
150(15)\end{array}$ & $\begin{array}{c}45(6) \\
120(14)\end{array}$ \\
\hline 胞狀細胞曆 & $\begin{array}{r}60(4) \\
180(8)\end{array}$ & $\begin{array}{r}55(3) \\
120(6)\end{array}$ & $\begin{array}{r}45(3) \\
45(3) \\
120(6)\end{array}$ & $\begin{array}{l}30(2) \\
90(6)\end{array}$ \\
\hline 原生海綿骨層 & $\begin{array}{l}135 \\
300\end{array}$ & $\begin{array}{l}150 \\
150\end{array}$ & $\begin{array}{r}60 \\
75 \\
300\end{array}$ & $\begin{array}{r}60 \\
120\end{array}$ \\
\hline
\end{tabular}

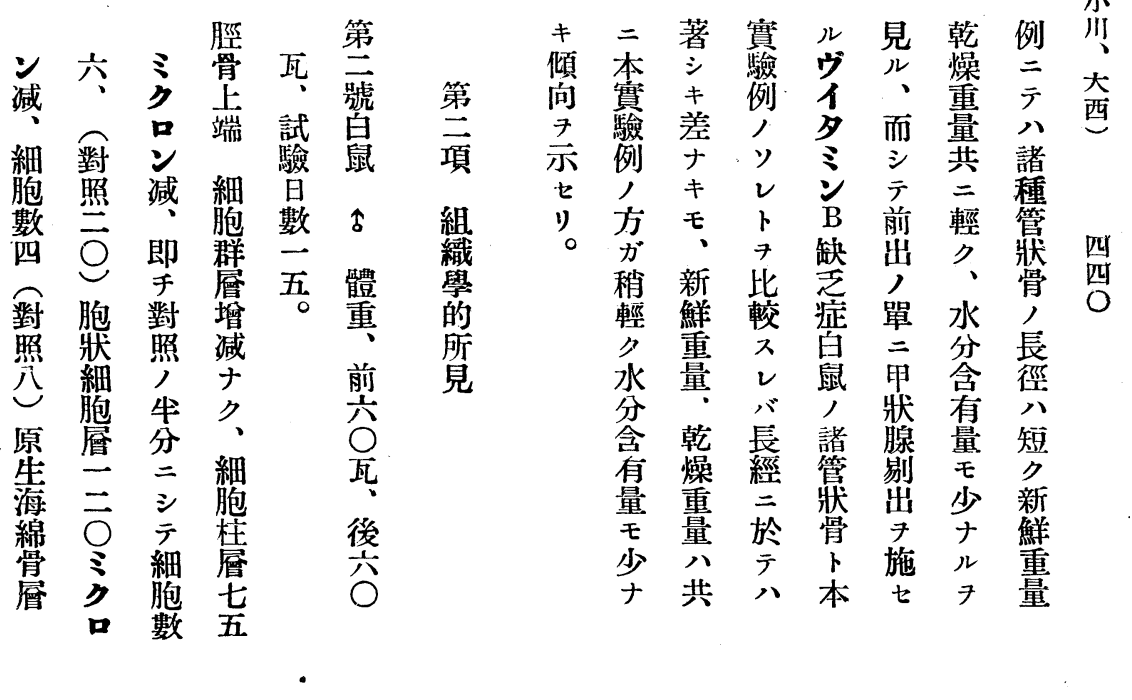




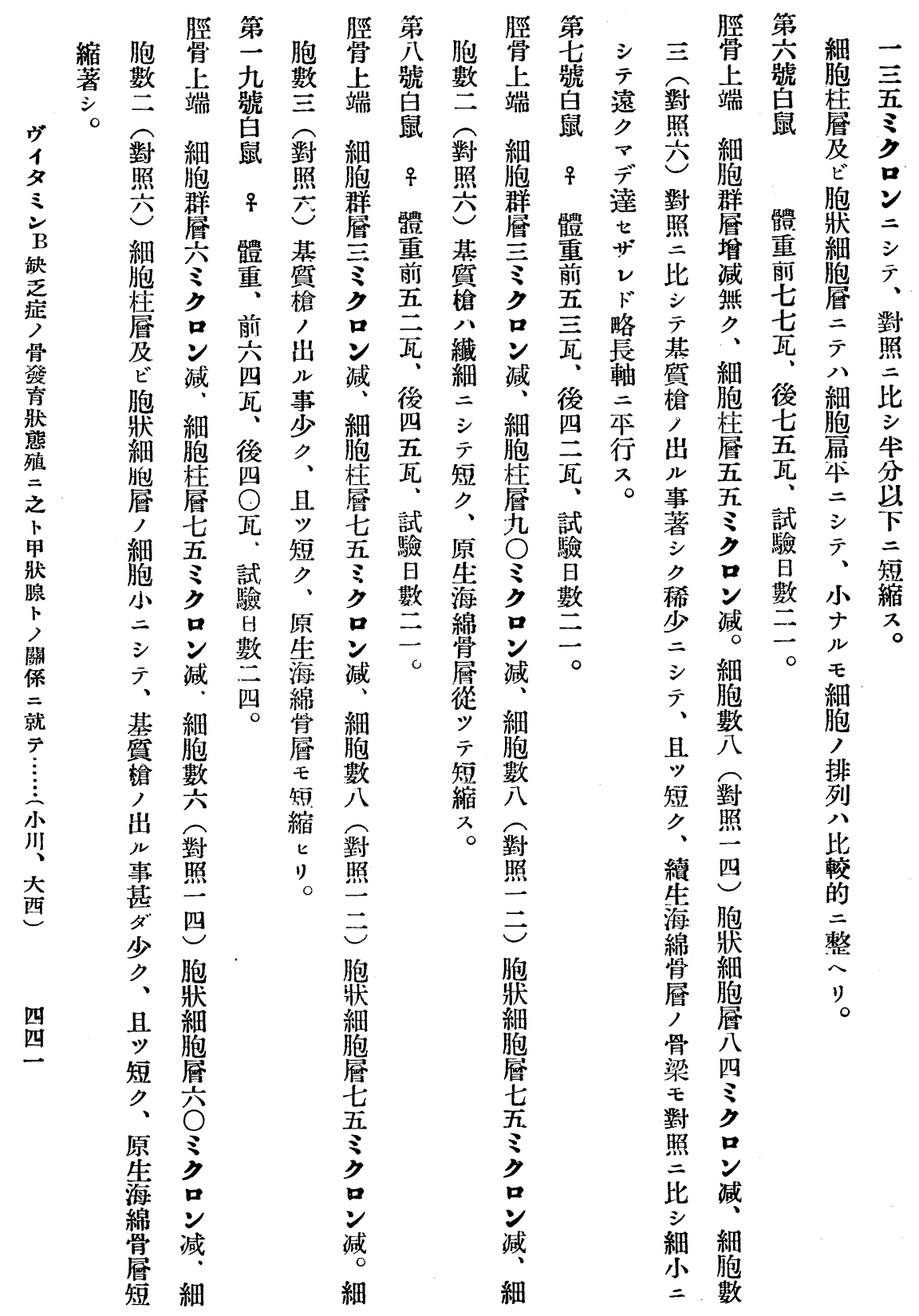




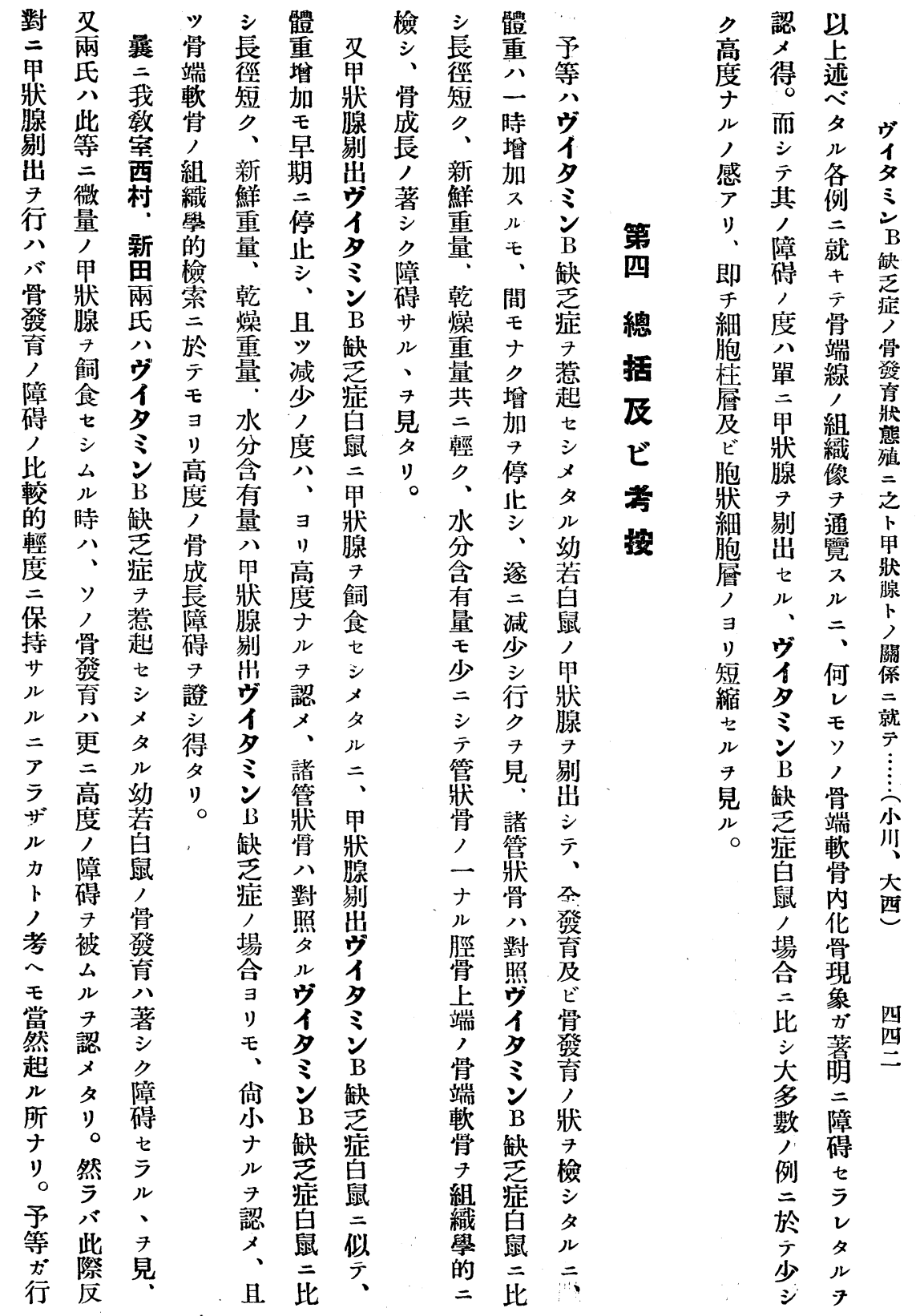




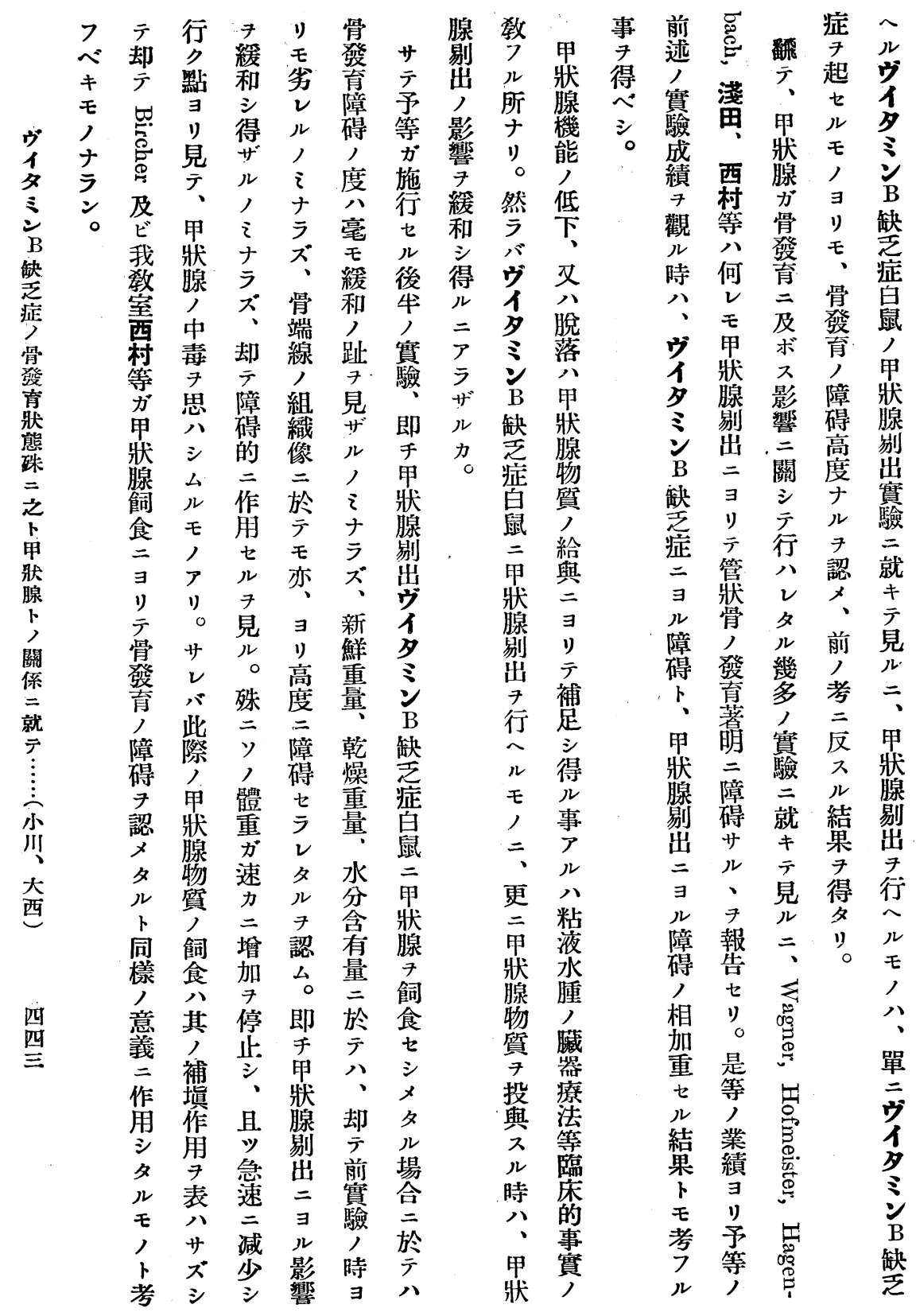




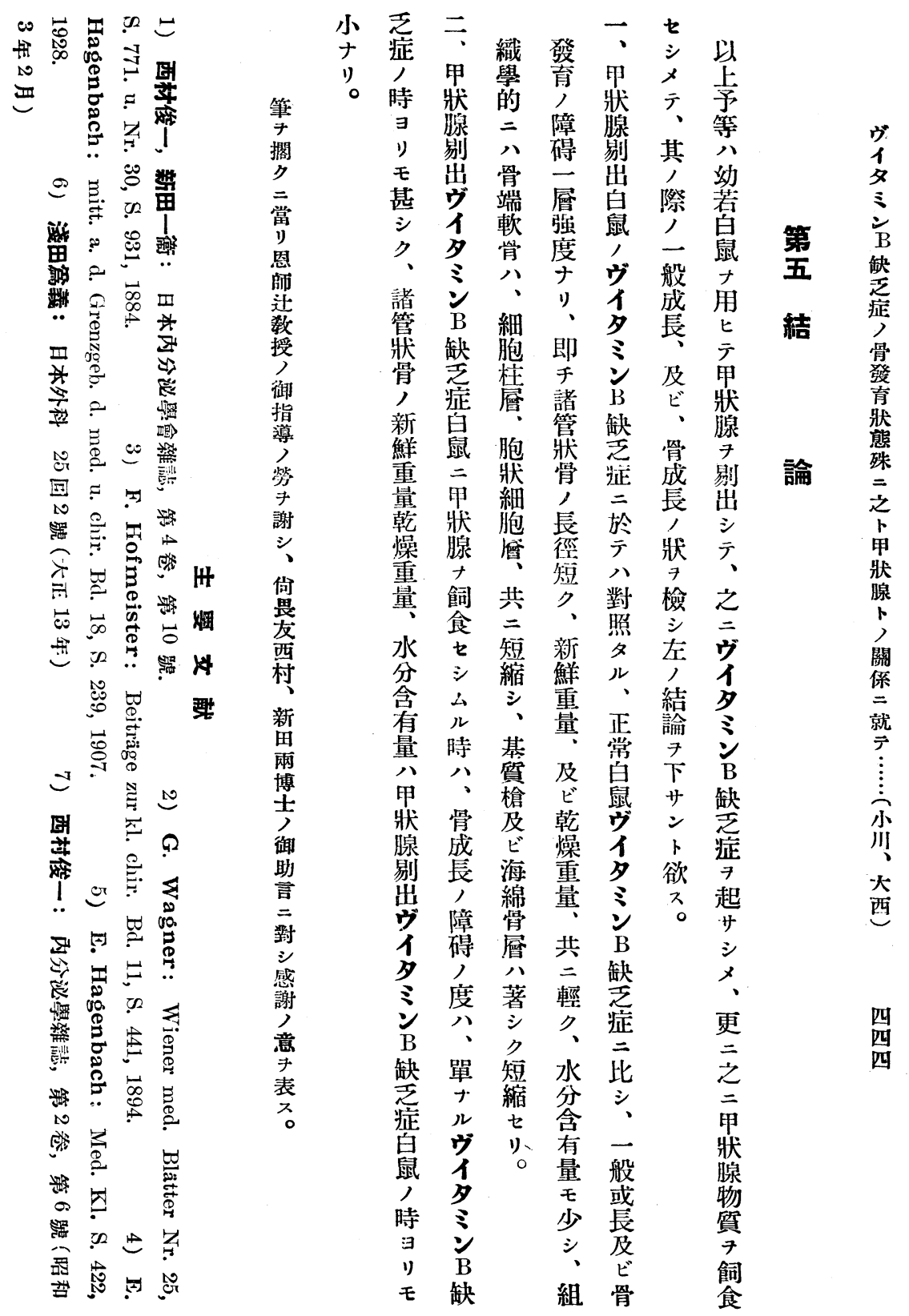


Fig. I.

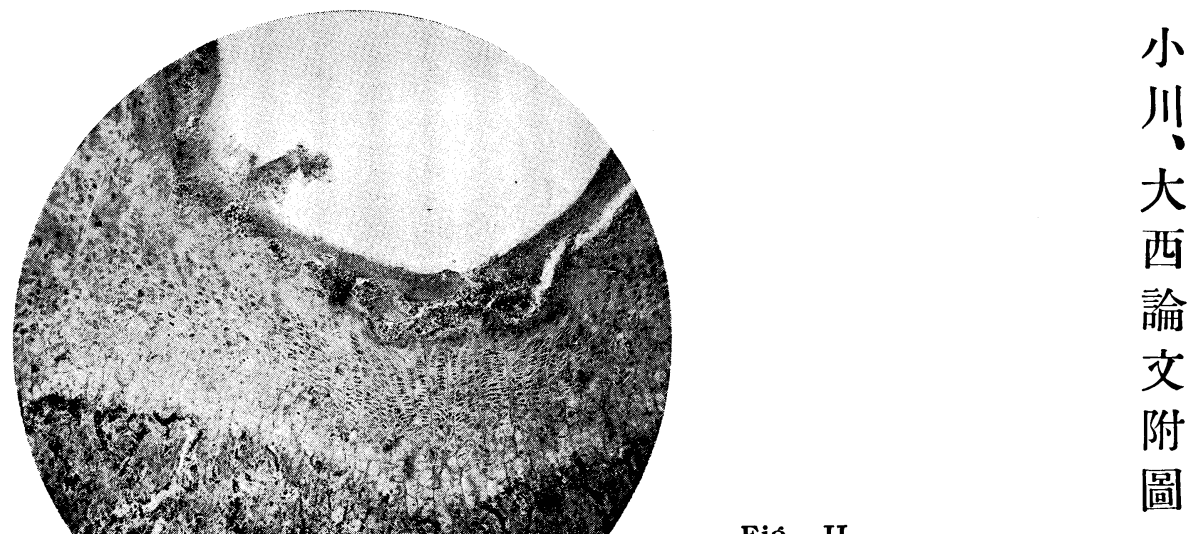

Fig. II.

Fig. III.
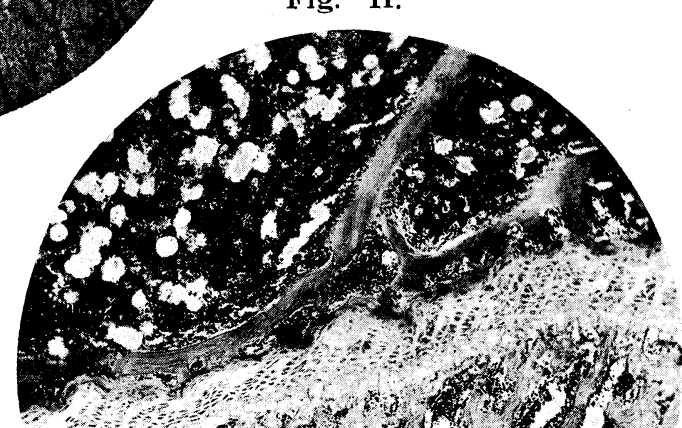

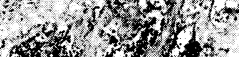
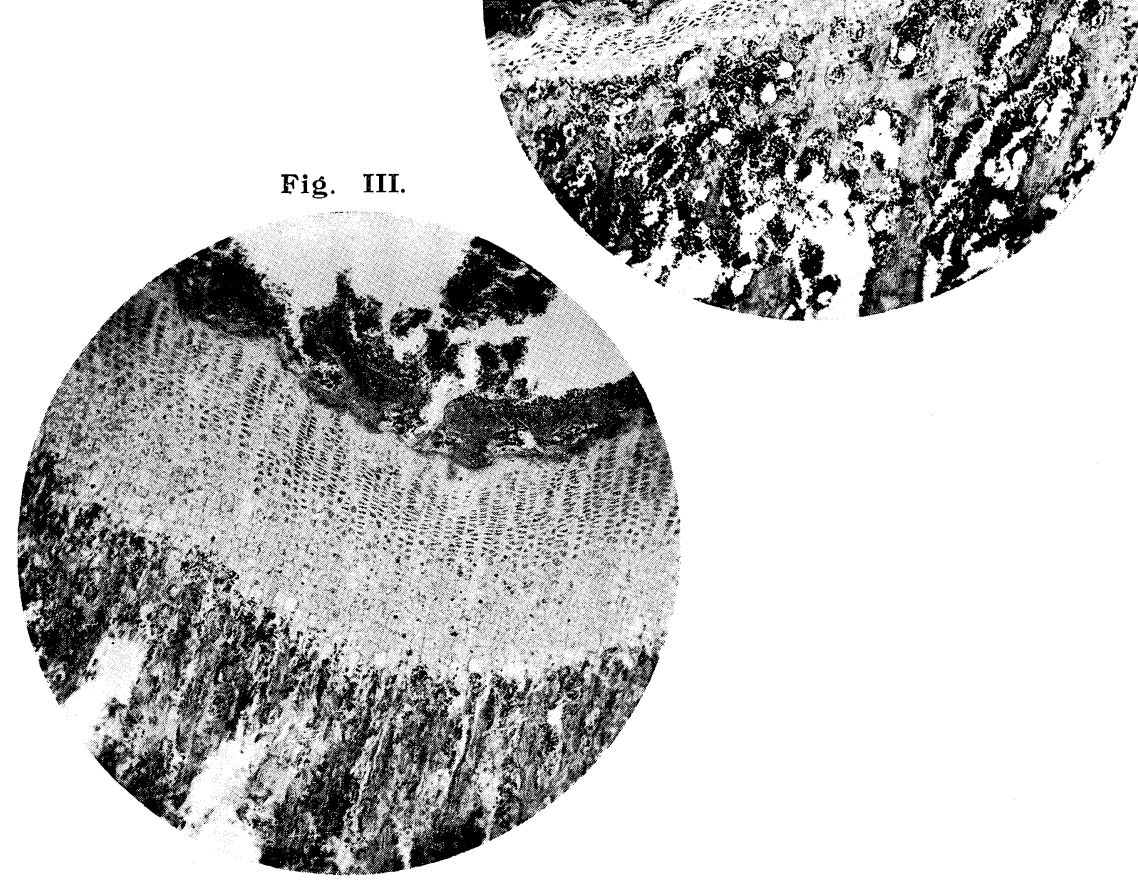


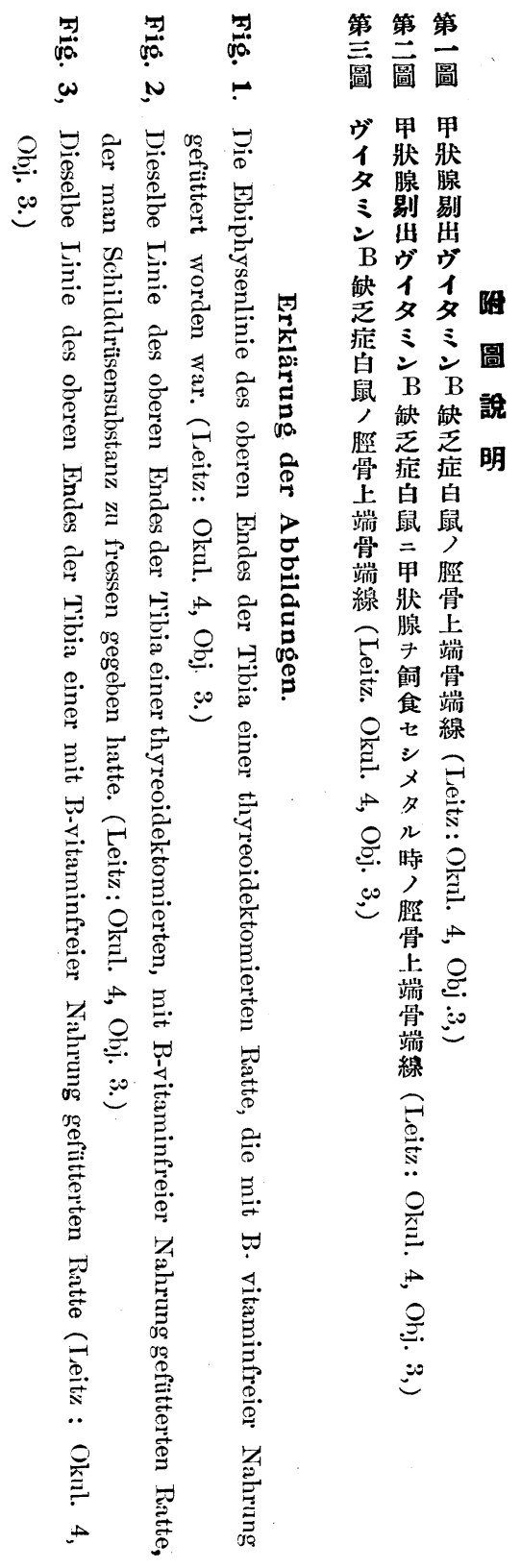


geringe Vermehrung.

2) An den normalen und den kastrierten Hunden vermehrten sich das Körpergewicht und der. Gesamtstickstoff im Harn. Der Harnsäure-und Allantoinstickstoff im Harn zeigten Vermehrung. sowohl in der absoluten Menge als auch im Prozentsatz zum Gesamtstickstoff. Diese Tatsache war deutlicher beim kastrierten Hund als beim normalen.

3) Der Kreatininstickstoff vermehrte sich in der absoluten Menge, und der Prozentsatz zum Gesamtstickstoff liess Neigung zur Vermehrung erkennen. Die Menge des Kreatinstickstoffes war sehr gering bei der Ernährung mit halbgereinigtem Reis, Laktogen und Sojasauce, schien aber bei der Injektion von Hodenextrakt zuzunehmen.

II. Bei der Hodenexstirpation (6 oder 7 Wochen nach der Operation). Der Gesamt-,Kreatinin-und Harnsäurestickstoff hatten in der absoluten Menge abgenommen. Aber der Prozentsatz zum Gesamtstickstoff zeigte im Vergleich mit dem normalen Werte keine deutliche Veränderung. Der Allantoinstickstoff liess sowohl in der absoluten Menge als auch im Prozentsatz Abnahme erkennen.

Nach dem obigen darf man schliessen, dass der Hodenextrakt keinen deutlichen Einfluss auf den Stickstoffwechsel, besonders nicht auf den Purinstoffwechsel der Hündin ausübt, aber beim normalen und beim kastrierten Hunde den Stickstoffwechsel und den Purinstoffwechsel beschleunigt. Die Hodenexstirpation hemmt besonders den letzteren.

(Autoreferat)

\section{Ueber den Einfluss der Schilddrüse auf das Knochenwachstum bei B-avitaminose.}

$$
\text { Von }
$$

Dr. T. Ogawa und Dr. Y. Ohnishi.

(Aus der I. med. Klinik der Kaiserl. Universität zu Kyoto, Japan. Direktor: Prof. Dr. K. Tsuji.) 
Wir untersuchten den Einfluss der Schilddrüse auf das Wachstum, besonders auf das der Knochen von mit B-vitaminfreier Nahrung gefütterten jungen weissen Ratten.

1) Von den mit B-vitaminfreier Nahrung gefütterten Tieren zeigten die thyreoidektomierten im Vergleich mit den nichtthyreoidektomierten stärkere Störung des Wachstums, besonders der Knochen. Es fand sich nämlich bei allen Röhrenknochen makroskopisch Abnahme der Länge und des Wassergehalts, und das Gewicht dieser Knochen war leichter sowohl im frischen als auch im getrockneten Zustande. An den Epiphysenfugen war histologisch die normale Zellwucherung merklich gestört und die Epiphysenlinie schmal, besonders an der Stelle der Knorpelsäulen und in der hypertrophischen Zone. Die Zellen der Zone waren meistens verkleinert und getrübt und zeitweise die Kerne völlig verschwunden. Die Zellanordnung war auffallend unregelmässig. Die primäre Spongiosa hatte abgenommen, und die mitten im Mark vorhandenen Knochenbälkchen waren dünner und kürzer.

2) Bei den thyreoidektomierten mit B-vitaminfreier Nahrung gefütterten Tieren hatte die Darreichung einer geringen Menge Schilddrüsensubstanz zu stärkerer Störung des Knochenwachstums als bei den Kontrolltieren geführt. Der Wassergehalt und das Gewicht der Röhrenknochen waren geringer als bei der Kontrolle. Die histologische Untersuchung ergab auch ein dem makroskopischen Bild entsprechendes Resultat.

(Autoreferat)

\title{
Ueber die histologischen Veränderungen der innersekretorischen Organe nach Alttuberkulininjektion.
}

\author{
Von
}

Dr. S. Yoshino

(Aus der I. med. Klinik der Kaiserlichen Uni ersisät zu Kyoto, Japan.

Direktor: Prof. Dr. K. Tsuji.) 